\title{
Aborto en Chile: \\ ¿Usas cartera Louis Vuitton o bolsa plástica?
}

\section{Tamara Vidaurrázaga ${ }^{1}$}

En Chile el derecho al aborto existe. Según el tamaño del bolsillo de cada quien.

Cada mujer podrá o no tener acceso a este derecho en relación al dinero con que cuenta. Entonces las más ricas se irán fuera del país y llegarán "repuestas" después de una semana. Otras harán el esfuerzo para pagar una intervención quirúrgica con un valor superior a los mil dólares. Muchas buscarán ilegalmente el Misotrol con una falsa receta para la gastritis o en el mercado negro, e interrumpirán en sus casas con el susto mediante. $Y$ quienes carezcan de recursos y herramientas acudirán al consejo de la amiga, la hierba ancestral, la caída por la escalera o hasta mover muebles pesados, a ver si "la regla por fin baja".

En un país como Chile, que además de patriarcal es capitalista, no existen ciudadanos ni ciudadanas. No existen seres humanos con derechos y libertades. Los derechos son -como todas las cosas- otro bien de consumo que podemos adquirir o no según nuestro potencial económico.

Y el aborto ni siquiera es un "bien de consumo básico", como la educación que el Estado intenta garantizar aún cuando no brinde garantías de calidad. El aborto es en -estos días y para las mujeres chilenas- un bien de consumo accesorio y de lujo. Cual cartera de marca reconocida, tipo Louis Vuitton.

La que tenga recursos económicos podrá adquirir este "bien-aborto" con la mayor de las seguridades. Y las que no, gran mayoría de este país, tendrá que contentarse con la "copia del producto", exponiéndose a condiciones inseguras que pueden llevarla al hospital producto de complicaciones, a la cárcel si es descubierta, o en el peor de los casos a la muerte, si no sabe ponerle atajo a una hemorragia y carece de ayuda a tiempo. 
Según un estudio realizado en toda Latinoamérica en los 90, de 10 nacimientos 4 y medio son deseados. Dos no son deseados, y 3 y medio terminan en abortos provocados. ${ }^{2}$

Esta cifra que extraña a algunas personas, así como la estimación de 160 mil abortos anuales, no es una sorpresa para cualquier mujer que pregunta y presta oídos a sus amigas, hermanas, madres, tías, abuelas. Lo que sorprende es que la supuesta razón de orden moral católico, no es sino una conveniencia de clases, con un objetivo claro para quienes ostentan el poder: mantenerse en él. Mientras el resto -incluyéndonos a la gran mayoría de las mujeres- tengamos que parir cuantos hijos e hijas incubemos, no importando que vivan después sin comida, techo, educación, salud o protección. El fin de estos niños y niñas no es, en la cabeza de los poderosos, lograr que sean felices; sino ser mano de obra barata para que nada cambie en el status quo. He ahí el meollo del asunto, y no en los credos religiosos.

El mismo estudio ya mencionado, evidenció que 8 de cada 10 mujeres urbanas con mayores recursos accedían a procedimientos abortivos practicados por profesionales de salud capacitados; en cambio, esa posibilidad solo la tenía 1 de cada 20 mujeres pobres rurales y 2 de cada 10 de las urbanas pobres. Al mismo tiempo 7 de cada 10 mujeres rurales pobres y 6 de cada 10 urbanas pobres, se auto provocaban el aborto o recurrían a personas sin capacitación. Y en consecuencia, eran mayoritariamente ellas las que sufrían complicaciones: 5 de cada 10 mujeres rurales pobres, 4 de cada 10 urbanas pobres, y solo 1 de cada 10 urbanas con mayores recursos $(1994,81)$.

O sea, ante la misma decisión de interrumpir un embarazo, una mujer urbana con recursos tiene 16 veces mayor seguridad que una mujer rural y pobre.

En Chile unas van por la vida con sus carteras Louis Vuitton y acceden a interrupciones de embarazo más seguros, mientras otras andan con la bolsa plástica y carecen de mínimas condiciones de seguridad sanitaria.

Otra cosa es si te tocó nacer en Europa o Estados Unidos. En ese caso, la Organización Mundial de la Salud señala que una mujer que interrumpe un embarazo en Chile corre un riesgo entre 100 y mil veces mayor que aquella que toma la misma decisión en Estados Unidos o Europa $(1994,101)$. 
Ya sabemos a qué clase pertenecen las que corremos mayores riesgos. Las otras, las que lucen carteras de diseño, se cuentan entre las gringas.

\section{Notas}

1 Integrante de la agrupación Feministas Tramando (www.feministastramando.cl).

2 Los datos fueron extraídos del informe elaborado por The Alan Guttmacher Institute, "Aborto clandestino, una realidad latinoamericana". New York y Washington: 1994, 89. 